\title{
Knowledge Sharing in China-UK Higher Education Alliances
}

\author{
Xiaoqing Li*, Joanne Roberts^, Yanni Yan ${ }^{\circledR}$ and Hui $\operatorname{Tan}^{\#}$
}

* Newcastle Business School, Northumbria University, Newcastle upon Tyne, NE1 $8 S T, U K$.

^ Winchester School of Art, University of Southampton, Park Avenue, Winchester, Hampshire, SO23 8DL, UK.

${ }^{\circledR}$ Marketing Department, College of Business, City University of Hong Kong Kowloon, Hong Kong, China.

${ }^{\text {\# } S c h o o l}$ of Management, Royal Holloway, University of London, UK.

\begin{abstract}
Knowledge sharing through cross-border strategic alliances has been seen by firms as one of the critical strategies to pursue sustainable competitive advantage. However, empirical investigations on how knowledge sharing occurs in strategic alliances are limited and are rarely concerned with strategic alliances in the higher education industry. Based on an empirical investigation of China-UK educational alliances, this research sheds light on this under explored area. Findings reveal that the scale of academic and organizational knowledge sharing is affected by knowledge attributes and partner characteristics. While knowledge sharing in China-UK higher education alliances displays numerous similarities with that occurring in other industries, this study reveals features that are distinct to this important and increasingly international sector. In so doing, this paper offers valuable insights for managers and policy makers concerned with the internationalisation of higher education.
\end{abstract}

Key words: strategic alliances, knowledge sharing, higher education

International Business Review, 2014, 23 (2), 343-355 


\section{Introduction}

Since the 1990s knowledge sharing has been seen by firms as one of the critical strategies required to sustain competitive advantage, this is because 'the integration of knowledge' is central to a firm's competitive capability (Grant, 1996, p.375). This increased attention to knowledge sharing coincided with the rise of cross-border strategic alliances (Bleeke \& Ernst, 1995). However, the mainstream literature has focused on what factors influence knowledge sharing, but few empirical studies have investigated how what and who factors influence the extent of knowledge sharing in strategic alliances (Meier, 2011).

Discussion of knowledge sharing in business alliances has been mainly focused on testing what factors could possibly influence knowledge sharing, such as the attributes of knowledge (Choi \& Lee 1997; Kogut \& Zander, 1993; Zander \& Kogut, 1995), partner characteristics (Grant \& Baden-Fuller, 2004; Lane \& Lubatkin, 1998; Mowery, Oxley \& Silverman, 1996), partner interaction (Mowery et al, 1996; Nielsen, 2007; Park \& Russo, 1996; Schoenmarkers \& Duysters, 2006), learning (Argote, 1999) and alliance governance structure (Chen, 2004; Inkpen, 2000; Kogut, 1988; Mowery et al 1996; Sampson, 2004). However, the majority of the research has focused on singular interrelations between these sets of factors, and only a small amount of research has adopted an integrated and interactive approach to examine how the what (knowledge attributes) and who (partner characteristics) factors influence knowledge sharing (Chen, 2004). In addition, the existing research relies heavily on the private sector as the principal source of theoretical development. This has conceptually constrained our understanding of knowledge sharing that has taken place in alliances in a wider range of industries, including the higher education (HE) sector (Rashman, Withers \& Hartley, 2009).

Driven by globalization, Higher Education Institutes (HEIs), namely universities, have 'expanded their provisions all over the world through strategic alliances to enhance their influences, visibility, and/or market share on the international scene' (Denman, 2000, p.5). Knowledge acquired through cooperating with an international partner helps universities stand out from the crowd (Chen, 2004). Saffu and Mamman (2000, p. 511) examined 22 Australian universities involved in alliances and found that $71 \%$ of those engaged in offshore activities were motivated by sharing knowledge with overseas partners. Between 2006 and 2009, the number of international joint venture campuses in the global HE industry increased by 43 per cent, to 162 (OBHE, 2009). The UK, with 13 international joint ventures, is ranked number three after the US and Australia (Becker, 2010). Among the host countries, China is ranked in second position after the United Arab Emirates (Becker, 2010). By 2005, there were more than 1,000 products offered by foreign universities in China, serving a total of 100,000 students and forming a key component of the Chinese HE sector ( $\mathrm{Li}, 2008$ ). Among these products, the largest portion (19.8\%) was provided by UK universities (MOE, 2011). However, research on how international alliance partners share 
knowledge in the HE industry is rare, and particularly in relation to China-UK alliances. To address this paucity of research this paper investigates knowledge sharing in China-UK HE alliances. In particular, the paper is guided by the following research questions: First, how and to what extent do partners in different forms of China-UK educational alliances share their knowledge? Second, how do knowledge attributes and partner characteristics influence knowledge sharing in China-UK educational alliances?

The paper begins with a review of the extant literature on how knowledge attributes and partner characteristics influence knowledge sharing in business alliances and assesses its relevance for understanding HE alliances. The two propositions that frame the study are derived from this review. A discussion of the research methodology employed follows in which we explain why the case study method was selected as the main research instrument and how the data were collected and analyzed. The findings are then reported and discussed in relation to the key research questions and propositions. Finally, the implications of the findings for research and practice are considered.

\section{Literature review}

\subsection{Knowledge attributes and knowledge sharing in strategic alliances}

Knowledge attributes affect 'what' is shared. Zack (1999) defines knowledge as accumulated information gained via experience, communication or inference. Knowledge exists in explicit and tacit forms. Explicit knowledge can be codified or articulated (Inkpen \& Dinur, 1998) and remains within the organization after employees leave (Coukos-Semmel, 2003). It is normally transmittable in formal, systematic language and may include explicit facts, axiomatic propositions, and symbols (Kogut \& Zander, 1993). In contrast, tacit knowledge is often non-verbalised, intuitive, and unarticulated (Polanyi, 1966). It manifests itself in cognitive, technical (Johnson-Laird, 1983) and social (Lam, 1997; Spender, 1996) dimensions. The cognitive dimension refers to beliefs, images, intuition and 'mental models' (Nonaka, 1994); the technical dimension refers to the 'know-how' applicable to specific situations (e.g. crafts). For Polanyi (1997), cognitive and technical knowledge is also described as theoretical knowledge (knowing what) and practical knowledge (knowing how). Social knowledge is embedded in social interactions and team relationships within organizations (Lam, 1997), as such, it is socially constructed (Evans and Easterby-Smith, 2001). Recognising that knowledge is more than an artefact that can be possessed, Orlikowski (2002) notes that 'knowing' how to get things done in complex organizational work is a dynamic process rather than stable property of the organization's core competencies. Moreover, tacit knowledge is central to knowing.

In HE, Coukos-Semmel (2003) classifies knowledge into two types: academic or scholarly knowledge, and non-academic organizational knowledge. The production and dissemination of academic knowledge represents the primary purpose of 
universities, while organizational knowledge, which refers to the accumulated overall management experience, is required to support a university's primary purpose (Coukos-Semmel, 2003). Both types of HE knowledge exist in explicit and tacit forms. However, the distribution between academic or organizational knowledge, whether explicit or tacit, is not clear, and a conceptual framework to differentiate between the various types of knowledge in HE is necessary (Guzman \& Trivelato, 2011).

Drawing on the existing literature concerning the nature of knowledge, the classification of academic and organizational knowledge in HE, and, importantly, the in-depth understanding of knowledge in the HE sector accumulated by authors, who have an average of 20 years' lecturing and administrative experience in $\mathrm{HE}^{1}$, this study classifies HE knowledge into four types as shown in Table 1: explicit academic knowledge, tacit academic knowledge, explicit organizational knowledge and tacit organizational knowledge.

Explicit academic knowledge exists in the forms of textbooks, course outlines and teaching slides, which serve one aspect of the university's primary purpose, that is, the dissemination of knowledge. For example, course outlines allow uniform course distribution and development (Guzman \& Trivelato, 2011), and books represent a key means of transmitting explicit knowledge in HE (Teichler, 2004). With respect to teaching, the tacit aspect of academic knowledge is gained from experience and embedded in individual lecturer's mental models and skill sets (Guzman \& Trivelato, 2011). According the UK's Higher Education Academy (HEA, 2012), teaching knowledge entails the following six dimensions: core knowledge of subject material, an appropriate appreciation of methods for teaching, knowledge of how students learn, the ability to use and value relevant technologies, an understanding of methods for evaluating the effectiveness of teaching, and knowledge of the implications of quality assurance and enhancement procedures. Moreover, tacit academic knowledge underpins pedagogical practices (Guzman \& Trivelato, 2011).

Insert Table 1 about here

Organizational knowledge is 'the capability members of an organization have developed to draw distinctions in the process of carrying out their work in particular concrete contexts, by enacting sets of generalizations whose application depends on historically evolved collective understandings and experiences' (Tsoukas \& Vladimirou, 2001, p.983). The existing literature claims that organizational knowledge has either a single category, namely knowledge embedded in organizational routines (Bontis \& Crossan, 1999) or exists in different types, for

\footnotetext{
1 Three of the authors have experience working in both Chinese and UK HEIs. In addition, the first has held a senior management position in the international office of a Chinese HEI.
} 
example, systemic, social-political and strategic (Evans \& Easterby-Smith, 2001), or strategic and technical (Child \& Rodrigues, 1996). Although there is no consensus on a classification of organizational knowledge, it is commonly accepted that organizational knowledge has tacit and explicit dimensions, which are like the two sides of a coin rather than separate entities (Evans \& Easterby-Smith, 2001). Explicit organizational knowledge refers to 'objectified knowledge' that is encoded in organizational practices, procedures and routines (Evans \& Easterby-Smith, 2001, p.5). Therefore, in HE explicit organizational knowledge is reflected in an organization's policies, business plans, databases, directories or accounting procedures (Coukos-Semmel, 2003). Tacit organizational knowledge is not owned by any specific individuals, it is embedded in groups and teams, and also reflected in organizational routines and informal procedures (Nelson \& Winter, 1982) or applied in key business processes and hence well known by insiders (Evans \& Easterly-Smith 2001; Lam, 1997). Tacit organizational knowledge is developed over time and accumulated through experience (Lenard-Barton, 1992; Ravetz, 1971). It is sticky (Szulanski, 1996), ambiguous (Teece, 2003) and complex. In HE, tacit organizational knowledge includes research excellence, management know-how, and organizational culture and experience.

Research excellence is not only reflected in a university's research volume and quality (Williams, 1992) but more importantly explains 'why some universities are home to a large number of departments that are successful at research' (Curran, 2000, p.386). It implies a context in which the necessary infrastructure and culture exist to attract and retain talented scholars (Curran, 2000). Therefore, the superior knowledge acquired over time in competing for research is contextual, path-dependent and engrained in people and the organization. Excellence in research is a source of competitive advantage, helping a university to enhance its reputation and thereby its ability to attract funding and talent students and staff.

Organizational culture is the 'pattern of basic assumptions that a given group has invented, discovered, or developed in learning to cope with its problems of external adaptation and internal integration, and that have worked well enough to be considered valid, and, therefore, to be taught to new members as the correct way to perceive, think, and feel in relation to those problems' (Schein, 1984, p.3). It explains why a group behaves the way it does, and it is the key to organizational excellence (Schein, 1984). Organizations with a strong culture normally demonstrate superior performance (Peters \& Waterman, 1982). The organizational culture in HE is characterized by its 'collegiatlity', where there is a shared decision-making process with a collegial style system of governance. The academic community work together to seek the best answers to issues facing the university through shared responsibility and decision-making power (Bartell, 2003; Fralinger, Olson, Pino-Zippp \& DiCorcia, 2010; Hellawell \& Hancock, 2001). However, organizational culture is always in the process of formation and change (Schein, 1984). For instance, in recent years, the collegial character of HE organizational culture has been challenged by the rise of a 
more managerial culture in many universities (Christopher, 2012; Keenoy \& Reed, 2008).

Management know-how refers to various types of management expertise employed in the basic functions of the organization (Negandhi, 1968). It involves the application of mangers' tacit knowledge about the organization for its future requirements (Dyerson \& Roper, 1991), and it is, therefore, organization-specific tacit knowledge (Montazemi, Pittaway, Saremi \& Wei, 2012). In HE, management know-how is a key contributor to a university's success. It is reflected in the managers' decision-making process, managerial style, the rationale of the strategic vision, and the capability acquired by performing well in various managerial domains (Simonin, 1999). Despite the differences between the various types of knowledge identified in Table 1, it is important to note that they are mutually dependent and interact with one another. The four types of knowledge are integrated assets underpinning the key functions of a university.

The more codifiable and transferable knowledge is, the more likely it will be shared (Kogut \& Zander, 1993). Tacit knowledge is embedded, context specific, personally bounded and, consequently, hard to share between organizations. Therefore, sharing tacit knowledge is more costly and time consuming than sharing explicit knowledge within as well as across organizational and national boundaries. In addition, partners are reluctant to share tacit knowledge as it relates to competitive advantage (Lyles \& Salk 1996; Thuc Anh, Baughn, Minh Hang \& Neupert, 2006). Tsoukas (2003, p. 410) emphasizes that 'tacit knowledge can only be displayed and manifested in what we do', therefore sharing tacit knowledge occurs through 'learning by doing', observation and intensive communication. Anderson (1983) classifies it as 'procedural knowledge', which is organizationally embedded (Kogut 1988, p.323), and hence, knowledge sharing requires individuals from different organizations to engage in shared practice where strong operational integration exists between both parties (Fineman, 2003; Fox, 2000). In addition, tacit knowledge sharing often requires co-location and co-presence, namely, the transfer of know-how requires a process of show-how (Roberts, 2000).

Importantly, the sharing and use of explicit knowledge may require the simultaneous sharing of tacit knowledge (Roberts, 2000) as 'explicit knowledge must rely on being tacitly understood' (Polanyi, 1966, p.7). Consequently, when analyzing the sharing of explicit knowledge it is necessary to consider what tacit knowledge is involved in the process. Moreover, when personal interaction happens across borders, cultural differences between alliance partners increase the difficulties of sharing tacit knowledge (Kedia \& Bhagat, 1988). This is because interpreting and sharing tacit knowledge requires individuals to share a common socio-cultural institutional framework (Roberts, 2000), which may be difficult to achieve in cross-border strategic alliances. Furthermore, cultural distance is likely to increase the likelihood of incompatibility between the combining firm's practices resulting in implementation 
problems (Bjorkman, Stahl \& Vaara, 2007) and reduced information flows (Lyles \& Salk, 1996), thereby impairing knowledge sharing (Mowery et al, 1996; Simonin, 1999).

Due to its immobility and inimitability, tacit knowledge is a source of competitive advantage (Ambrosini \& Bowman, 2001). In HE, tacit organizational knowledge is more difficult to develop than tacit academic knowledge (Chou Yeh, 2005, p.36; Coukos-Semmel, 2003). Tacit organizational knowledge is built up over a prolonged period of time, therefore it cannot be acquired easily. In contrast, tacit academic knowledge, most of which is embedded in individuals' experience and minds, can be acquired by hiring experienced staff.

In $\mathrm{HE}$, academic and organization knowledge vary in relation to the degree to which they are explicit or tacit, and, therefore, they also vary in term of the ease with which they may be shared. For instance, where knowledge is deeply ingrained in an individual's experience it may not be accessible to that individual in a form that may be articulated. Such knowledge is highly personal (Polanyi, 1962), and although it may be developed in an organizational context it is not easily accessible to others in the organization (Ambrosini \& Bowman, 2001). Therefore, the sticky characteristic of tacit knowledge increases the difficulties of sharing it. Among the four types of knowledge, it is tacit organizational knowledge that drives engagement for long-term competitiveness in international strategic alliances. This leads to our first proposition:

Proposition 1: In China-UK HE alliances, various types of knowledge are shared between partners; however, tacit organizational knowledge is the most difficult to share yet the most important for long-term competitiveness.

\subsection{Partner characteristics and knowledge sharing in strategic alliances}

The key elements discussed in extant research concerning partner characteristics in knowledge sharing in international strategic alliances are partners' motivation, competitive overlap and absorptive capacity. Grant and Baden-Fuller (2004) claim that organizations seek alliance opportunities in order to either access or acquire knowledge through cooperation. Buckley, Glaister, Klijn \& Tan (2009, p.600) argue that knowledge accession aims to exploit the existing knowledge of the partner(s) to achieve synergies. For instance, when alliance partners A and B are motivated by knowledge accession, both sides contribute knowledge to the alliance, resulting in a new stock of combined specialized knowledge, which helps the partners to realize a common goal that cannot be accomplished independently. The flow of knowledge is from $\mathrm{A}$ and $\mathrm{B}$ to the alliance, but there is no knowledge flowing back from the alliance to $\mathrm{A}$ and $\mathrm{B}$. 'The nature of the combination process is not based on knowledge exchange, but rather a process of inputting knowledge into the focal unit' (Ibid, p.599). Therefore, knowledge accession does not rely on learning, as the partners are interested in the amalgamation of existing knowledge rather than 
absorbing new knowledge. The combined specialized knowledge may be reflected in a new product or service. For instance, in HE, this might be a new degree course targeting a specific market with the combined inputs of universities A and B. Indeed, alliances can offer access to new markets and critical local knowledge (Makino \& Delios, 1996), and 'the synergetic effects arising from knowledge accession should enhance the competitiveness of the alliance, resulting in higher obtainable economic rents for each of the partners' (Buckley et al, 2009, p.600).

In contrast, knowledge acquisition emphasizes the partners' aim of acquiring knowledge in order to learn. In this case, although existing knowledge flows from A and B to the alliance, new knowledge learned from the alliance flows back to A and B. Therefore, alliances for acquiring knowledge have stronger learning intent than alliances for accessing knowledge. Partners who are ambitious to acquire tacit organizational knowledge will commit to an alliance through deploying resources to facilitate knowledge sharing (Beamish \& Berdrow, 2003). However, an over intention of learning may have counterproductive effects on knowledge sharing, because partners would be protective of their knowledge if they suspect their partner's intention (Norman, 2002, 2004), particularly when partners compete in similar end product markets (see also Mowery et al. 1996).

Therefore, the openness of knowledge sharing is determined by the competitive overlap between alliance partners. Partners from a similar industry background who do not compete directly seem to be less protective of their knowledge than those who are active in a common market (Meier, 2011). The former situation exerts lesser competitive pressures on the alliances, as partners are less concerned with unintended knowledge sharing (ibid). At the same time, partners from the same industry who do not compete directly enjoy an overlap of their basic knowledge, and this supports mutual understanding and facilitates knowledge sharing (Lane \& Lubatkin, 1998). Put another way, the overlap in basic knowledge enhances partners' absorptive capacity and therefore the ability to share knowledge (Cohen \& Levinthal, 1990; Steensma \& Lyles, 2000). Consequently, companies motivated by acquiring knowledge, which are from a similar industry background but do not compete directly, are more willing to exchange their knowledge with partners and intend to learn (Kim, 1998), than those that are motivated by accessing knowledge even though they are from the same industry and do not compete directly.

In China-UK HE alliances, the UK HEI is comparatively more advanced than the Chinese HEI in terms of research capacity, reputation and ranking (Shanghai Jiaotong University, 2008). In addition, the UK universities do not compete with Chinese universities in the same market as they draw the majority of their customers from their respective domestic market. China-UK HE alliance partners are from the same industry and have a similar knowledge base, which leads to high knowledge absorptive capacity (Park, 2011). In this situation, how much knowledge is shared between partners is mainly subject to their motives. Previous research suggests that 
the more non-codifiable knowledge assets, like reputation and brand, are shared with overseas subsidiaries, the more commitment is required to monitor the overseas operation (Buckley \& Casson, 1976); this is particularly the case for knowledge intensive services. Moreover, Li and Roberts (2012) reveal that when UK universities enter China, those motivated by market seeking tend to employ low commitment entry modes, while those seeking to enhance their reputation and pursuing long-term goals adopt a high commitment approach. This suggests that universities that are motivated to acquire a greater variety of types of knowledge through forming alliances should be willing to make a greater commitment to knowledge sharing than those that are motivated by knowledge accession, even though high commitment means higher costs of involvement. Hence, we assume that:

Proposition 2: China-UK HE alliances that are motivated by acquiring competitive knowledge demonstrate greater commitment to sharing a wider variety of types of knowledge than those that are motivated by accessing knowledge.

\section{Methodology}

\subsection{Case study method}

Jankowicz (1991) claims that appropriate research methods and techniques depend on the research problem and its purpose. Qualitative research methods compared to quantitative technique are more suitable for studying organizations, groups and individuals (Strauss \& Corbin, 1990) when the objectives of the study demands in-depth insight into a phenomenon (Ghauri, Gronhaug \& Kristianslund, 1995). As Daft (1980) argues, the complex, intangible, emotional dimensions of organizations cannot be processed through the fine filter of linear statistics. This research is to investigate how and why the nature of knowledge and partners' characteristics influence knowledge sharing in educational alliances. Hence, we adopt a qualitative approach and employ an in-depth multiple case study method (Yin, 2003) as the key instrument to help draw out insights on knowledge sharing in international strategic alliances in the HE sector.

To identify key representative cases, we adopted a macro to micro approach. We started from the secondary data (MoE, 2011; QAA, 2006) to acquire an overview of China-UK collaboration in HE. In 2003 the Chinese government started to permit joint ownership rights for foreign universities, although fully owned foreign universities are still not permitted. The general picture showed a very striking feature of China-UK educational alliance, namely, that there were only two JV campuses, accounting for about $1 \%$ of all China-UK educational alliances. This signal sent from the macro picture reminds the researchers that the micro scope of the research should include distinctive forms of cooperation, particularly the $1 \%$ of JVs. More importantly, this also means that there is an unbalanced distribution of the various types of cooperative forms among China-UK educational alliances. Non-JVs dominate accounting for $99 \%$ of all China-UK educational alliances. Therefore, adopting a quantitative method could result in the neglect of the $1 \%$ of JVs, thereby 
distorting the analysis about how knowledge sharing takes place across China-UK collaborations in HE.

Based on this step, we classify educational alliances into two types: equity JV and non-equity alliances based on Pan and Tse (2000). Non-equity alliances vary depending on whether students engage in learning across borders. According to our observation, students in most of the HE alliances move between two countries to consume a degree programme. If a degree course is entirely taught in China with no movement of students between countries, this kind of cooperation is defined as a single-based alliance (SB). On the other hand, if a degree course is split in both countries, and students move from one country to the other to complete the same degree programme, the alliance is categorised as a dual-based form (DB). The latter has two sub-types: validation and franchise according to whether the courses taught in China are validated or franchised by the UK partner universities. Therefore, 20 cases were carefully chosen to cover the composite categories of both equity alliances and non-equity alliances covering key forms of China-UK educational alliances. Each case had been in operation for at least two years to allow evaluation and comparison of knowledge sharing practices and results. Eventually, the study succeeded in accessing 13 cases, but the case information for each type was saturated when the total number of cases reached ten. The secondary data showed that, at the time of the study, only 2 UK universities were engaged in the equity JV form and 52 in non-equity forms. Consequently, an examination of the 10 case studies selected for detailed examination reflects $100 \%$ of the equity JV alliances, and $38 \%$ of the non-equity alliances (Table 2). The sample of case studies included in this research not only covers a substantial portion of the total population China-UK HE alliances but also provides a good representation of the various alliance forms evident in the population. Consequently, the case study selection process ensured that the research was based on an appropriate and sufficient set of data.

Insert Table 2 about here

\subsection{Data collection}

Our data were collected through interviews conducted in the ten case study alliances, and desk research of secondary information gleaned through records available in the public domain. A pilot study was conducted in the UK with a single-based case, followed by fieldwork in both China and the UK between 2008 and 2009. In all, 41 interviews were conducted with 20 organisations involved in the ten cases. Interviews took place in the interviewees' offices within the Chinese or UK universities. Interview lasted between 1 hour 30 minutes and 2 hours 40 minutes and they were all recorded with the prior agreement of the interviewees. The interview questions were semi-structured, thereby giving interviewees a certain freedom to express their own opinions on a particular issue. Nevertheless, the framing of the questions was predetermined, so that the interview contents could be controlled and 
key issues highlighted. Interviews were conducted with those responsible for the cooperative project at various levels of the hierarchy, including Chancellor/vice-chancellors (UK) or president/vice president (China), deans/heads of the departments who were involved in the formation and operational phases, project directors, coordinators, and academic members of staff who engaged in the project.

\subsection{Data analysis}

There is no standardized approach to the analysis of qualitative data due to its diverse nature (Coffey \& Atkinson, 1996; Dey, 1993; Miles \& Huberman, 1994). After verifying the collected data through triangulation by comparing the information and evidences gathered, all the data were content analysed. This involved the following steps: firstly, based on the research propositions, the frequency and relevance of key variables and their influence upon the success of knowledge sharing in educational alliances were identified, while recognizing relationships within and between categories of data (Saunders, Philip \& Adrian, 2003); secondly, the key sub-variables which have a bearing on the importance of the variables noted, and the factors which create and/or influence these were identified; finally, the meaning and implications of the findings were deduced. All the interview transcripts from the ten cases were cross-searched for the variables. Then the method of 'pattern matching' (Yin, 2003) was employed, and the patterns of variable were then translated into analytical and theoretical language (Weber, 1990). This evidence and analyses were finally constructed into the findings. Representative interview quotations were included to support our argument. The detailed themes and categories of data analysis are shown in Table 3.

As Saunders et al. (2003, p.260) note, it is difficult to control bias. This study adopted a number of methods to reduce bias. Firstly, the extant literature was thoroughly explored to ensure that the propositions emerged from a comprehensive review of theories. Alongside this, the authors sought feedback from experts in the field on the propositions and incorporated such feedback into their refinement and the design of the field work. Secondly, each case was approached from both the UK and China perspective, this allowed the views from both sides to be compared and contrasted. Thirdly, each interview was thoroughly prepared and conducted, for instance, background information about the two partners' universities and the project was studied before the interview, the approach to questioning was carefully planned, and the nature and purpose of the research was explaining at the beginning of each interview (Saunders et al., 2003, p.254). Fourthly, to ensure the validity of the data the interview accounts were triangulated with information from other sources, such as documents, and observations during the interviews. In particular, some interviews were conducted twice at key points in the study to double check and validate the interview information. Fifthly, the whole data analysis process was regularly communicated with experts through the presentation of conference papers and the key themes emerging from the data analysis were discussed and validated by two leading 
experts in the field of international strategic alliances. ${ }^{2}$ Finally, the executive findings of the study were also informally presented to the case study universities; the feedback received was valuable and incorporated into this research.

Insert Table 3 about here.

\section{Findings}

\subsection{Knowledge characteristics and knowledge sharing}

Sharing knowledge, particularly academic knowledge either explicit or tacit, through cooperation was highlighted by the interviewees. The protection of knowledge was seen by partners as a 'paranoid' response to collaboration in the ten cases. Instead, as the following quote demonstrates, openness to knowledge sharing was the norm:

'They can take anything they want from us (UK side). I have worked in academic world for several decades, I feel there is no meaning to protect, as no matter how advanced knowledge you have, you can only lead in that area for a short term.' (Pro-Vice- Chancellor, UK, JV2).

Explicit academic knowledge was easily shared in the ten cases through exchanging course outlines, teaching slides, textbooks and assessment materials. However, in cases where the nature of the courses delivered in China resembled the UK features, there was recognition of the importance of tacit knowledge to facilitate the sharing of explicit academic knowledge. As a Module leader (UK, DB franchise 3) explains:

'I know my teaching is here (London) this week, I know this module is also being taught in Egypt, Dubai, Hong Kong and China this week as well. So when I design what I'm going to do this week with students in London, I have to think very carefully how this can be translated and taught all over the world. I make it as explicit as possible, but this cannot guarantee that the local tutors in another part of the world can interpreted it $100 \%$ in the same way.'

One of the means adopted by partners to facilitate knowledge sharing through learning by doing and demonstration is to move UK staff to China. As a UK seconded president at a China campus (JV1) noted 'it is not just what we teach. The more interesting thing is how we do it.'

\footnotetext{
${ }^{2}$ See acknowledgements for details.
} 
However, the tacitness of courses varies (Guzman \& Trivelato, 2011) and there are difficulties in sharing academic knowledge when the degree of taciness is high. For example, the tacit aspect of teaching arts could not be completely shared:

'It is easy to share the materials we have, but we need people with similar capabilities to teach it in China. We are very good at art, but it's not easy to share the teaching of art. They cannot teach art just with your notes, you need to have staff with the same thinking and the way they look at art should be the same as the course designer's (concept)'. (Head of China Management Centre, UK, DB franchise 3)

In such cases, explicit academic knowledge is difficult to share without tacit understanding (Polanyi, 1966) because the course designer could not articulate and write down all his or her expert knowledge and abstractive thinking (Guzman \& Trivelato, 2011). Perspectives on the same art might differ substantially between the tutors located in the UK and China. In such cases, the co-location of the staff is central to sharing tacit academic knowledge.

As for organizational knowledge, no difficulties were experienced by the interviewees in sharing explicit organizational knowledge. Nevetheless, it was recognised that the application of this type of knowledge was subject to the partners' need to adapt to the local context. In contrast, and as suggested in proposition 1, tacit organizational knowledge seemed to be the most difficult type of knowledge to share. Indeed, while tacit academic knowledge, which is more individual based, was shared by the case study alliances through the mobility of staff, tacit organizational knowledge required higher levels of commitment and took longer for partners to share. The comments of a Dean from the China partner (Case 3) is indicative of the challenges involved in the sharing of tacit organizational knowledge:

'I stayed one year there (partner university, UK) in the purpose to share our knowledge in management. I'm impressed by their distinct organizational culture where people are so responsible and eager to learn. The communication is highly efficient and everyone is committed to teamwork with full energy in teaching and research. But I feel so difficult to bring this back as I could not describe exactly why and how it has developed.'

Hence, sharing of tacit organizational knowledge requires intensive interaction through learning by doing. Difficulties increases when the sharing of management know-how takes place between people from different culture background. For example, the seconded president of the China campus in both JVs noticed that, in dealing with daily management routines, the Chinese colleagues did not make decision themselves so everything was put to the president, which slowed down the communication. The seconded presidents in both cases had to organize a lot of informal and formal meetings to make the Chinese colleagues gradually understand 
the UK style of management. This failure to adapt quickly to the UK style of management might be the result of cultural differences or due to the receiver's lack of sufficient understanding of the partner's organization and social context where the knowledge was developed and originally embedded.

In addition to the challenges of sharing management know-how, both JV cases highlighted the process of sharing research expertise between the UK and China partner. Research expertise was shared through various means. First, both sides jointly supervised $\mathrm{PhD}$ students, who registered in the UK, and divided their time 50:50 between China and the UK. Second, research centres were established which focused on the research interests of staff at the China campus. In the case of JV1, the number of research centres had been developed from 2 in 2004 to 8 by the end of 2011. The staff on both sides collaborated together targeting challenging research areas (air pollution, sustainable energy, innovative industry technology), which were of significance to densely populated and developing countries like China. In the case of JV2, building on the strengths of both partners, research areas addressed cutting edge fields including nanotechnology and new materials, 4G wireless technology, and metabolic syndrome drug research. Consequently, joint papers between the seconded staff and the JV university staff were published; public lectures, and international conferences were hosted on the China campuses; joint projects received substantial funds from the UK's Economic and Social Research Council and from national and local Chinese governments. These activities intensified the communication between the partners and promoted the sharing of tacit research expertise leading to the development of the JV university's own research capacity. Moreover, burgeoning research centres in the JV campus helped to attracted and retain excellent staff in China. As the following quote demonstrates, staff in China benefitted from engagement with UK colleagues and, in so doing, developed their own tacit knowledge of research processes:

'It is difficult to describe what I learned exactly from my colleagues (seconded staff from the UK) through this research project, it is a valuable experience; what I'm sure is that it is impossible for myself to get it done on my own to this high quality; but after this, I'm confident to implement an independent research project in the future.' (Staff, China, JV2).

At the same time, both parent universities' research excellence was enhanced, for instance, the Seconded Provost, from the UK partner in JV1 noted:

'We (the UK university) want to become a leading centre of Chinese studies in Britain, the success of the China campus could be a boon for us to achieve this.'

Nevertheless, the China based research centres developed in fields that were distinctive from those areas for which the UK partner universities were highly ranked 
at home, thereby providing scope for both partners to acquire new knowledge from the alliance.

Among the ten cases, partial tacit organizational knowledge sharing is evident in the two equity JV alliances and only to a much lesser extent, in the form of management know-how sharing, in the two non-equity SB alliances. Partners were aware that tacit organizational knowledge, such as research excellence, organizational culture and management know-how, which underpin the UK universities' reputation, were context-based and path-dependent, and therefore difficult to share. As a result, interviewees emphasized the need for a JV university to develop its own excellence in the long-term:

'They don't have to replicate what we are doing here. The JV campus will think about developing their own prestige, which may or may not be near what we are doing here (the UK university). But it has to be on their own, has to meet their needs. They should own rather than just taking the whole thing from us. They have done that in initiation when they need a system there. But they must grow into a mature university to find a better way for them.' (Director of planning, UK, JV2)

The evidence detailed above supports Proposition 1, which suggests that the nature of knowledge influences the extent of knowledge sharing between partners in China-UK HE alliances. Although the evidence indicates that the partners shared various types of knowledge, tacit organizational knowledge proved the most difficult to share due to its complexity, organizational embeddedness, and the social interaction required. At the same time, the stickiness of tacit organizational knowledge ensures that it provides a sustainable source of competitive advantage for universities.

\subsection{Partners' motivation in forming China-UK HE alliances and its impact on knowledge sharing}

The partners' motives in forming China-UK HE alliances varied between the equity JVs and other non-equity alliance forms. A motivation to acquire knowledge and engage in learning were clearly evident among the two JV cases. The following comment from a UK Pro-Vice Chancellor (JV2) illustrates this motivation:

'China is an important country, we need to know about, to interact and engage with China, this (establishing a JV campus) is a very solid, practical and concrete way of doing it.'

Accessing knowledge to generate extra income through collaboration motivated partners to employ non-equity alliance forms. A healthy institutional relationship with a prestigious university in China could bring a steadier stream of high quality students 
than working with agents or individual students in a rapidly changing global market. Therefore, a non-equity alliance provides a means to mitigate a weak position in the home market.

'Clearly we want revenue from additional students. This (alliance) can diversify our customer base, internationalize our university and widen our profile; it gives us a greater chance to survive as a modern institution' (Coordinator, UK, DB-franchise1)

Different motivations in forming alliances led to differences in partners' commitment to the collaboration. Partners in both equity JV cases are willing to deploy resources to support knowledge sharing. In the case of JV1, 60,000 English books were contributed to the new campus by the UK side, making the JV university the premier university in the local area with the highest number of English books. Staff and students in China, like those in the UK campus, are free to access the University's resources, for instance, to request books from the library in the UK, or access career information in the UK. In contrast, the strong financial pursuit of the non-equity alliance cases demonstrated a common reluctance to deploy resources to the alliance partners in China. The following UK partner attitude towards the Chinese partner in a non-equity alliance was representative:

'They (the Chinese partner) approached us and didn't require anything particularly different to what we are doing now. We are just drawing up an agreement, and just keep going. There is no financial implication at all.' (The coordinator, UK, DB Validation 1)

More importantly, in both equity JVs, the commitment of the UK partners was demonstrated by the secondment of staff to China. The plan was for one third of the staff at the China campus to be seconded from the UK for the long-term. Indeed, the majority of the first seventy-two professors in the case of JV1 were contributed by the UK side to help the China campus build up a foundation capable of the overall operation. Similarly, in the case of JV2, leaders of academic faculties and other functional departments, covering administration, human resource, financial management, quality control and so on, were also filled by UK staff. However, high commitment means high costs. For example, the seconded staff enjoyed the UK standard salary plus an additional 30\% expatriate fee; while in non-equity forms, where no seconded staff were engaged, the extra fees acquired through the alliance were largely spent on transport and accommodation for fly-in/out or visiting staff members. The greater the involvement of UK staff in the course delivery, the higher the associated costs would be.

Despite its higher cost, a high commitment structure offers a better platform for a variety of knowledge sharing than a low commitment structure. In the two equity JV cases daily operational problems were solved together on-site in a face-to-face 
manner through interaction and socialization, thereby promoting the acquisition of tacit organizational knowledge. In particular, personnel rotation though expatriate assignments is found to be a key method of knowledge sharing (Argote, 1999; Nonaka \& Takeuchi, 1995), so the presence of key personnel on a JV campus for the long term facilitated the sharing of tacit knowledge through learning by doing. As the following interviewee reveals:

'I was in China responsible for quality insurance, we must satisfy the requirements of the Ministry of Education, China first. Interestingly, they did not just send us forms to fill in, they asked that, this is the criteria we have for assessing the quality for a university, what do you think. I said we do it in this way, but they were more interested in how we do it rather than what we do. So we have a lot of interaction with them on how we do these things. Through these, I also learned a lot, e.g. how our system fits in the Chinese context, where and how we can benefit each other, and how we can achieve it through the real practices.' (Seconded president, UK, JV1)

Interviewees from the JV cases repeatedly referred to learning from their partners, underlining their motivation to acquire knowledge. The UK side perceived that a campus in China will provide a base to extend and continue research collaborations with international firms that have moved their $\mathrm{R} \& \mathrm{D}$ centres to China. In particular, the UK partners in the JVs expected to learn how a Western course would interface with an Eastern course in practice. In contrast, partners selecting a non-equity alliance form regarded an equity JV strategy as risky for their reputation, slow to establish and costly. Partners in non-equity China-UK HE alliances demonstrated a strong desire to exploit the existing resource to access the Chinese market for financial gains. The desire to access rather than acquire knowledge for extra income generation seemed increasingly stronger from SB alliances to DB franchise and is at its highest among DB validations.

In a SB non equity alliance form, the cooperation jointly running one or two courses, provided opportunities for individual staff members to enhance their teaching and broaden their experience, and hence benefitted home students. Under this structure, taking the case of SB1 as an example, a 3-year UK undergraduate degree course was extended to 4 years, which was 50:50 taught by both sides, but entirely delivered in China; the final year dissertation was split between two parts. Students received dual degrees awarded by each partner. The two sides have intensive communication on the delivery of the joint courses when the fly-in/out staff visited the China campus, and when the joint academic and steering committees met (twice a year). Consequently, the knowledge shared is mainly academic and limited to the department or individual level. This limit to the type of knowledge shared was also reflected in a strong intention to exploit existing resource to the full. For instance, the UK partner of SB2 was planning to set up a three region project running the same programme in China, Vietnam and India. In this way, staff could repeat their teaching 
and resources would be fully exploited. In the case of SB1, the successful model was also transplanted in other departments in the UK side, for instance, the medical school was negotiating to set up a partnership with the same model in India. Again, the knowledge that flowed back to the UK was still mainly academic, with tacit organizational knowledge sharing limited to the department level, namely how to manage one or two joint courses in different countries. Tacit organizational knowledge, such as research excellence and organizational culture, was rarely shared.

In non equity DB alliance forms, either franchise or validation, partners' were very much motivated by gaining access to the Chinese market to recruit non-EU students. In a DB form of arrangement, the part of the course taught in China (e.g. 2 years in China followed by 1 year in the UK) was delivered by local staff. The UK partner sends members of staff to China once or twice a year, but the main purpose of their visit is mainly to interview students and issue offers ${ }^{3}$, or to help train Chinese staff to deliver the UK courses. In the franchises, the UK side shared all teaching materials with the local tutors and contact between UK and Chinese tutors is facilitated virtually through email, MSN or Skype. However, knowledge sharing was limited to the academic areas, namely, how to understand the shared teaching materials. In DB validations, where the part of a UK degree course taught in China was designed and taught by the Chinese side, the communication between two sides was very limited. In two out of three cases in this form of alliances, the UK side offered complete teaching materials. Yet, they did not monitor whether the Chinese side used these materials. The Chinese side randomly sent staff to the UK, accompanying students to observe how UK lecturers taught, although their own teaching in China was not 100 per cent in English. The management of students was divided between partners according to the students' location. Staff and students had no access to the UK resources when in China. Hence, no organizational knowledge was shared between partners in DB-validation alliances. Insufficient communication and interaction between partners in the DB validation alliances resulted in the lowest level of knowledge sharing among all forms of alliance structures.

The evidence from the 10 China-UK HE alliance cases suggests that a high commitment form is more conduce to the acquisition of tacit knowledge than low commitment forms. In particular, moving members of staff facilitated tacit academic and organizational knowledge sharing. Nevertheless, merely moving members of staff cannot move networks (Argote \& Ingram, 2000), if a web of coordinating relationships connecting specific resources is left in its original context. Hence, the sharing of tacit organizational knowledge requires more than the mobility of personnel, it is an arduous process requiring time and resources as the following interviewee noted:

\footnotetext{
${ }^{3}$ Offers to study at the UK partner university are issued to students if they demonstrate a specific level of attainment in their studies at the Chinese partner institution.
} 
'We are always open, you could access our methods, documents, and what we are doing, just from your desk. But if you want to learn from our university (UK) and what we have achieved, it would be an active process, it is a whole cultural re-orientation which takes a generation to reach that stage.' (Seconded president, UK, JV1)

The evidence summarised here shows that partners who are motivated by acquiring knowledge through equity based JV alliances are more willing to commit to the practices of knowledge sharing through deploying key resources to the alliances than those who are motivated by the accession of knowledge through non-equity alliances. This supports Proposition 2, that China-UK HE alliances that are motivated by acquiring competitive knowledge demonstrate greater commitment to sharing a wider variety of types of knowledge than those that are motivated by accessing knowledge. Knowledge acquiring alliances, namely equity JVs, seek to share tacit organizational knowledge as well as other types of knowledge. Figure 1 below summarizes the findings of this analysis as they relate to the two propositions emerging from the extant literature.

Insert Figure 1 about here.

\section{Discussion}

This paper examines the extent to which partners shared knowledge and how knowledge attributes and partner characteristics affect knowledge sharing between partners in China-UK HE alliances. Our findings shed light on the rarely explored subject of knowledge sharing in Sino-British HE alliances. Framed by a classification of four types of knowledge in HE, our results support the existing literature on international business alliances, that the extent of knowledge sharing is strongly influenced by what factor, namely, the attributes of knowledge (Chen, 2004; Kogut \& Zander, 1993). Tacit knowledge characterized by embeddedness, context specificity and non-codifiability (Newell, Robertson, Scarbrough \& Swan, 2002; Nonaka, 1994; Polanyi, 1962) is found to be more difficult to share than explicit knowledge. Compared to tacit academic knowledge, which is relatively independent and personal-based, tacit organizational knowledge is more systematic and organizational-based, hence, it is more difficult and costly to share than other types of knowledge. In some of the cases studied there is no evidence of tacit organizational knowledge sharing at all. In contrast, explicit knowledge is found to be widely and easily shared between partners in all cases. The findings also support the view that explicit knowledge sharing is often dependent on tacit knowledge sharing (Roberts, 2000). For example, it was found that the delivery by local tutors of art courses was difficult even when they had all teaching materials from the UK course designer. 
Consequently, the sharing of explicit knowledge relies on being tacitly understood (Polanyi, 1966) and the transfer of know-how requires a process of show-how (Roberts, 2000) in some specific areas in HE alliances. In addition, the findings of this study are in line with those of Mowery et al. (1996), Pak, Ra \& Park (2009) and Bhagat, Harveston and Triandis (2002), namely, that cultural differences between partners impedes tacit knowledge sharing especially tacit organizational knowledge sharing.

The findings show that the extent of knowledge sharing is also strongly influenced by who factor, that is, partners' motivation in forming China-UK HE alliances. Partners who are motivated by acquiring competitive knowledge actively engage in knowledge sharing and preferred to adopt high commitment arrangements, such as an equity JV by deploying sufficient resources. In contrast, partners who intended to access local markets through knowledge accession preferred low commitment forms of alliances, for instance, non-equity forms. Partners in non-equity alliance forms are more interested in the maximization and exploitation of existing knowledge, namely, sharing knowledge to attract students. The evidence shows that the majority of UK universities (99\%) involved in China-UK HE alliances are motivated to access rather than acquire local knowledge.

Alliances that are motivated by knowledge acquisition demonstrated strong ambition to acquire a variety of knowledge, in particular, tacit organizational knowledge, and an equity JV form of alliance offers a suitable platform to achieve this. First, procedural knowledge (Anderson, 1983), incorporated, for instance, in management know-how could be easily captured and shared through routines within a formal organizational structure. Second, an equity JV promotes intensive face-to-face communication (Easterby-Smith \& Araujo, 1999; Elkjaer, 2003; Hansen, 2002; Winter, 1987), which is particularly helpful for sharing research excellence. Third, a $\mathrm{JV}$, as an independent entity, could be developed into a fully-fledged university, where the organizational culture is shared and developed. Therefore, a JV can build new research centres, with implications for the sharing and co-creation of knowledge. Partners adopting high commitment equity JV arrangements seek to create platforms for co-presence and co-location to facilitate the sharing of tacit knowledge of all types (Roberts, 2000). In these alliances, the seconded staff located on the JV campus played an important role because they created opportunities for partners to share, observe and learn from each other through interactions in their daily jobs. This implies that dispatching personnel from the parent organization with long term assignments in the alliance is conducive to tacit knowledge sharing (Inkpen \& Dinur, 1998; O’Dwyer \& O’Flynn, 2005; Park 2011; Tsang, 2002). The knowledge acquired through the rotation of personnel on the China campus is internalized through a legal ownership governance structure. The positive impact on the UK parent universities included an increase in the internationalization of the curriculum, enhancing research capacity, the accumulation of international campus management expertise and experience, and the strengthening of reputation in the global HE market. 
Such advantages are absent in non-equity based China-UK HE alliances with an arm's-length contractual arrangement where the opportunity to learning through sharing is offered only on a short-term basis through visits from fly-in/fly-out staff in a SB form arrangement, limited virtual communications between the two partners in a DB-franchise, and rare or no contact between partner staff in a DB-validation. Therefore, our study supports the previous research by Kogut (1988), Tallman and Shenkar (1990), and Mowery et al. (1996), that tacit knowledge sharing is found to be more efficient through equity arrangements than non-equity alliances. However, higher costs occur in knowledge acquisition through equity JVs than knowledge accession through non-equity alliances. In particular, in China-UK HE equity JV alliances the maintenance of $1 / 3$ secondees on the China campus for the long term was found to be the most challenging task for both JVs studied.

The evidence also demonstrates the distinctiveness of knowledge sharing in public sector China-UK HE alliances when compared to private sector alliances. Firstly, people are central to knowledge sharing in China-UK HE alliances. This might be due to the nature of $\mathrm{HE}$ as a service largely derived from intangible inputs, with only low levels of tangible elements (Zackariasson \& Wilson, 2004, p.8). The core value of an educational service arises from the transformation of people's mind, which relies on the provider and consumer engaging in a coproduction process. This explains why labour added value accounts for $85 \%$ in the HE sector (Johal, 2009). Second, HE alliances exist in a world where the spread of knowledge through lectures, research, learned journals and books is the primary currency of life. In traditional private sector businesses, monopoly access to a body of knowledge can be a primary source of competitive advantage and a determinant of success and even survival. For these reasons the spread of knowledge is regarded very differently in the two worlds. While private sector managers are frequently protective of their organization's core knowledge, and rightly so, educationalists disseminate such knowledge freely and with pride.

Several factors account for the open attitude towards knowledge sharing in HE. Firstly, knowledge service transactions are different from the transactions of goods. Academics who share their academic knowledge with partners do not lose it only its exclusiveness (Marginson, 2004). However, 'this is compensated by reference to the origin of this knowledge through citation and by gain of reputation based on the creation of new knowledge' (Teichler, 2004, p.12). Indeed, knowledge increases in value as it becomes more accessible and formal (Anand \& Singh, 2011). Secondly, and in contrast to $\mathrm{HE}$, in private sector businesses there are tensions and risks involved when cooperation co-exists with competition between alliance partners. An alliance may result in a merger or an acquisition once one side achieves the original purpose of the alliance (Child, Faulkner \& Tallman, 2005). In comparison, as long as the alliance can recruit students, HE alliances have a long life. This study did not identify any evidence to suggest any intentions of one partner to taken over the other; 
whereas this is often how business alliances end (Bleeke \& Ernst, 1995; Brouthers \& Bamossy, 2006). The absence of such intentions promotes a cooperative atmosphere, which facilitates knowledge sharing in HE alliances. Third, in the private sector, if new knowledge is shared with an alliance partner there is a danger of facilitating the development of new competitor. In HE, students pay fees not only for learning skills and knowledge but also to acquiring a degree certificate. In China, a UK accredited degree not only provides validation of knowledge, experience and ability but also provides access to networks and enhances social status. This quality derives from the reputation of the UK HE and the reputation and brand value of UK HEIs. Consequently, although the Chinese university in an alliance could independently employ the knowledge and expertise gained through the alliance in the market, its ability to compete with the UK partner is limited by its inability to offer the accompanying UK degree. Therefore, the knowledge shared in China-UK HE alliance has little value without the accreditation process over which the UK partner retains strict control.

Finally, even in JVs where tacit organizational knowledge was shared through a real operation of the university, the core knowledge that provides the source of competitive advantage of a UK university is a combination of possessed knowledge on brand building, international networks, management expertise and leading research. It takes a long time for a recipient university to absorb and adapt the acquired expertise into its own competitive capability and most of the knowledge could not be shared and acquired through a JV alliance concentrated on limited areas. This implies that developing a university's own prestige and brand is important, and sharing such knowledge through establishing a China-UK HE alliance can speed up this process, but the journey is still long.

All in all, for partners engaged in JV China-UK HE alliance, the tacit knowledge acquired through running a campus in an overseas market and jointly running degree programmes could not be bought from the free market. Consequently, such alliances enhanced the competitive advantage of the partners over the long term. In contrast, knowledge accession through linking existing resources in a validation or a franchising alliance mode might be easily replicated by competitors. Hence, such forms of cooperation create little competitive advantage for partners in China-UK HE alliances.

\section{Limitation and implications for further research}

This research sheds light on an underdeveloped area, knowledge sharing in international education alliances. By investigating China-UK HE alliances, it reveals that explicit academic knowledge is shared freely between partners and that sharing does not weaken the competitive advantage of the UK institutions. The sharing of tacit academic knowledge, such as teaching skills can support the sharing of explicit academic knowledge. This suggests that practitioners managing HE alliances can 
openly share explicit and tacit academic knowledge with their partners. In contrast, tacit organizational knowledge, where the university's competitive advantage is originated, is more difficult to share or acquire quickly. Hence, current and future practitioners need to recognize that acquiring tacit organizational knowledge through alliances in HE is a long term undertaking. Those universities motivated merely by short term revenue generation will not be able to acquire through HE alliances the core valuable tacit organizational knowledge required to enhance their sustainable competitive advantage.

While we claim that this empirical study is the first investigation of knowledge sharing in China-UK HE alliances, we are aware of its limitations. Firstly, our research into equity based Sino-UK educational alliances is supported by data from only two such cases. The limited number and the short life of the two cases (one would be six years and the other eight years by 2012) has constrained the findings of this research. This limitation could be addressed by conducting more longitudinal investigations of the current cases or expanding this research to a wider range of countries where JVs in the HE sector are permitted by the host governments, for example, foreign campuses in Dubai and Singapore (Becker, 2010). Secondly, knowledge sharing in educational alliances in this emerging area is a dynamic and lengthy process. It is likely that the extent and the methods of knowledge sharing between partners would be influenced by newly introduced products or resource reallocation. It is difficult for us to capture a complete picture of the underlying motivation for all the dynamic changes. Finally, the measurement of the value of knowledge sharing in educational alliances is important, but it is an area that is currently poorly appreciated. The value may be reflected in the application of acquired knowledge in different aspects of educational alliances as well as their respective parent universities, for instance, improved students performance, more international oriented teaching or a stronger position in a the competitive global HE market (Li, Faulkner \& Yan, 2011). Hence, a comparison of the real attainment for those universities based on knowledge sharing through international alliances would be very meaningful.

\section{Acknowledgment:}

The authors thank Professor X and Professor Y, who acted as the first author's supervisors for the doctoral research from which this paper derives. In addition, the authors thank two anonymous reviewers for their helpful comments and suggestions. 
Table 1. Categories of knowledge in HE

\begin{tabular}{|c|c|c|}
\hline & Explicit & Tacit \\
\hline Academic & $\begin{array}{l}\text { - } \text { Course outline, } \\
\text { - } \text { Teaching slides } \\
\text { - } \text { Textbooks } \\
\text { - } \quad \text { Assessment strategies }\end{array}$ & $\begin{array}{l}\text { - Knowledge delivery } \\
\text { - Teaching style-learning by } \\
\text { doing } \\
\text { - Course design } \\
\text { - Course management }\end{array}$ \\
\hline Organizational & $\begin{array}{ll}\text { - } & \text { Policies } \\
\text { - } & \text { Procedures } \\
\text { - } & \text { Business plans } \\
\text { - } & \text { Data base } \\
\text { - } & \text { Directories } \\
\text { - } & \text { Accounting procedures }\end{array}$ & $\begin{array}{l}\text { - Research excellence (funding, } \\
\text { attracting and retaining research } \\
\text { experts ) } \\
\text { - Management know-how, } \\
\text { routines } \\
\text { - Organizational culture } \\
\text { - Experience }\end{array}$ \\
\hline
\end{tabular}

Table 2. Configuration of types of China-UK education alliances and data reflection

\begin{tabular}{|c|c|c|c|c|c|c|c|c|c|c|}
\hline \multirow{4}{*}{$\begin{array}{l}\text { Configuration } \\
\text { Case Number }\end{array}$} & \multicolumn{8}{|c|}{ Non equity } & \multirow{3}{*}{\multicolumn{2}{|c|}{$\begin{array}{c}\text { Equity } \\
\text { Joint } \\
\text { venture }\end{array}$}} \\
\hline & \multicolumn{6}{|c|}{ Dual based } & \multirow{2}{*}{\multicolumn{2}{|c|}{$\begin{array}{l}\text { Single -based } \\
\text { Joint } \\
\text { programme }\end{array}$}} & & \\
\hline & \multicolumn{3}{|c|}{$\begin{array}{l}\text { Dual based } \\
\text { Validation }\end{array}$} & \multicolumn{3}{|c|}{$\begin{array}{l}\text { Dual based } \\
\text { Franchise }\end{array}$} & & & & \\
\hline & $\mathrm{C} 1$ & $\mathrm{C} 2$ & $\mathrm{C} 3$ & $\mathrm{C} 4$ & C5 & C6 & $\mathrm{C} 7$ & $\mathrm{C} 8$ & C9 & $\mathrm{C} 10$ \\
\hline Length of operation & $2 y s$ & $7 \mathrm{ys}$ & $9 y s$ & 9ys & $6 y s$ & $5 y s$ & $4 y s$ & $5 y s$ & $2 \mathrm{ys}$ & $4 y s$ \\
\hline $\begin{array}{l}\text { No. of UK universities } \\
\text { in China in } 2011^{1}\end{array}$ & \multicolumn{6}{|c|}{38} & \multicolumn{2}{|c|}{14} & \multicolumn{2}{|c|}{2} \\
\hline No. of cases examined & \multicolumn{6}{|c|}{6} & \multicolumn{2}{|c|}{2} & \multicolumn{2}{|c|}{2} \\
\hline \multirow{2}{*}{ Data reflection \% } & \multicolumn{6}{|c|}{$24 \%$} & \multicolumn{2}{|c|}{$14 \%$} & \multirow{2}{*}{\multicolumn{2}{|c|}{$100 \%$}} \\
\hline & \multicolumn{8}{|c|}{$38 \%$} & & \\
\hline
\end{tabular}

Note: ${ }^{1}$ MoE, 2011 
Table 3. Summary of key categories emerging from data analysis

\begin{tabular}{|c|c|c|c|c|c|}
\hline \multicolumn{2}{|r|}{ Key themes } & \multicolumn{4}{|c|}{ Main categories } \\
\hline \multirow{7}{*}{\multicolumn{2}{|c|}{$\begin{array}{l}\text { Motivation } \\
\text { of } \\
\text { UK partners }\end{array}$}} & Case $9 \& 10$ & Case $7 \& 8$ & Case 4,5 \& 6 & Case $1,2 \& 3$ \\
\hline & & $\begin{array}{l}\text { In market through real experience } \\
\text { and control of a new university }\end{array}$ & $\begin{array}{l}\text { In marekt but being } \\
\text { cautious of risk and costs }\end{array}$ & In market at low cost & In market at low cost \\
\hline & & $\begin{array}{l}\text { Acquire competitive knowledge } \\
\text { and internalize through } \\
\text { ownership (50\%) }\end{array}$ & $\begin{array}{l}\text { Acquire knowledge by } \\
\text { jointly running } 1 \text { or } 2 \\
\text { courses }\end{array}$ & $\begin{array}{l}\text { Access academic } \\
\text { knowledge by } \\
\text { franchising the UK } \\
\text { course }\end{array}$ & $\begin{array}{l}\text { Access academic } \\
\text { knowledge by } \\
\text { validating the Chinese } \\
\text { course }\end{array}$ \\
\hline & & $\begin{array}{l}\text { Enhance reputation in the region } \\
\text { and global market to attract more } \\
\text { international students to the } \\
\text { China \& home campuses }\end{array}$ & $\begin{array}{l}\text { Indirect recruit students: } \\
\text { C7: undergraduates can } \\
\text { directly link to a Master } \\
\text { course in the UK }\end{array}$ & $\begin{array}{l}\text { Direct recruit } \\
\text { students }\end{array}$ & $\begin{array}{l}\text { Direct recruit } \\
\text { students }\end{array}$ \\
\hline & & $\begin{array}{l}\text { Strengthen competitive } \\
\text { advantage by exploring research } \\
\text { opportunities, acquiring } \\
\text { management know-how and } \\
\text { organizational experience }\end{array}$ & $\begin{array}{l}\text { Avoid risk of being } \\
\text { excluded from important } \\
\text { markets and broaden } \\
\text { individual staff } \\
\text { experience to improve } \\
\text { dimension of teaching }\end{array}$ & $\begin{array}{l}\text { Exploit academic } \\
\text { resources for income } \\
\text { generation: gain stable } \\
\text { student intake to } \\
\text { enhance survivability }\end{array}$ & $\begin{array}{l}\text { Exploit academic } \\
\text { resources for income } \\
\text { generation: gain stable } \\
\text { student intake to } \\
\text { mitigate the declining } \\
\text { domestic market }\end{array}$ \\
\hline & & $\begin{array}{l}\text { Apply the acquired competitive } \\
\text { knowledge in other countries }\end{array}$ & $\begin{array}{l}\text { Tansplant the acquired } \\
\text { experience in other } \\
\text { departments }\end{array}$ & & \\
\hline & & $\begin{array}{l}\text { Surplus re-invested in China } \\
\text { campuses }\end{array}$ & $\begin{array}{l}\text { Income reinvested in the } \\
\text { project }\end{array}$ & & \\
\hline \multirow{5}{*}{ 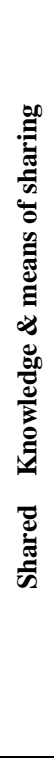 } & $\begin{array}{l}\text { No. of } \\
\text { programmes } \\
\text { shared }\end{array}$ & $\begin{array}{cc}\text { C9: } & \text { C10 } \\
28 & 9\end{array}$ & $\begin{array}{cc}\text { C7 : } & \text { C8: } \\
2 & 1\end{array}$ & $\begin{array}{ccr}\text { C4: } & \text { C5: } & \text { C6: } \\
6 & 4 & 2\end{array}$ & $\begin{array}{ccc}\mathrm{C} 1: & \mathrm{C} 2: & \mathrm{C} 3: \\
2 & 2 & 3\end{array}$ \\
\hline & $\begin{array}{l}\text { Teaching and } \\
\text { learning } \\
\text { materials }\end{array}$ & $\begin{array}{l}\text { Teaching: } \\
\text { slides, notes, outline } \\
\text { Learning: } \\
\text { on-line course, student email } \\
\text { account, live lecture, on-line } \\
\text { library, request books from } \\
\text { China }\end{array}$ & $\begin{array}{l}\text { Teaching: } \\
\text { slides, notes, outline } \\
\text { learning: } \\
\text { on-line course } \\
\text { student email account } \\
\text { live lecture }\end{array}$ & $\begin{array}{l}\text { Teaching: } \\
\text { slides, notes, outline } \\
\text { Learning: } \\
\text { on-line course } \\
\text { student email account }\end{array}$ & $\begin{array}{l}\text { Teaching: } \\
\text { slides, notes, outline } \\
\text { (C2\&3) }\end{array}$ \\
\hline & $\begin{array}{c}\text { Staff } \\
\text { communication }\end{array}$ & $\begin{array}{l}\text { Face-to-face: daily } \\
\text { Video conference: often }\end{array}$ & $\begin{array}{l}\text { Face-to-face: short term } \\
\text { MSN: often }\end{array}$ & $\begin{array}{l}\text { Regular visits } \\
\text { MSN, email }\end{array}$ & $\begin{array}{l}\text { Random visits } \\
\text { Direct communication: } 0\end{array}$ \\
\hline & $\begin{array}{l}\text { Committee } \\
\text { meeting } \\
\end{array}$ & $\begin{array}{l}\text { Face-to-face: often } \\
\text { Video conference } \\
\end{array}$ & $\begin{array}{l}\text { Face-to-face: twice a } \\
\text { year; On-line : MSN }\end{array}$ & $\begin{array}{r}\text { Face-to-face: } \\
\text { once a year } \\
\end{array}$ & No committee \\
\hline & $\begin{array}{l}\text { Research } \\
\text { centres } \\
\text { \&international } \\
\text { students } \\
\end{array}$ & $\begin{array}{l}\text { Research centres: 6-9 } \\
\text { international students: } 15-25 \%\end{array}$ & No & No & No \\
\hline \multicolumn{2}{|c|}{$\begin{array}{l}\text { Ease of different } \\
\text { types of } \\
\text { knowledge shared }\end{array}$} & $\begin{array}{l}\text { Academic: } \\
\text { explicit \& tacit: easily shared } \\
\text { Orgnizaitional: } \\
\text { explicit: easy } \\
\text { tacit: (partial, concentrate on } \\
\text { limited areas), icl. management } \\
\text { know-how, reserch expertise } \\
\text { organizational culture } \\
\text { \&experience }\end{array}$ & $\begin{array}{l}\text { Academic: } \\
\text { explicit: shared easily } \\
\text { tacit: shared by moving } \\
\text { staff temparily } \\
\text { Organizational: } \\
\text { explicit: easily shared } \\
\text { tacit (partical): } \\
\text { management know-how } \\
\text { limited to department } \\
\text { level }\end{array}$ & $\begin{array}{l}\text { Academic: } \\
\text { explicit: easily shared } \\
\text { tacit: difficult for high } \\
\text { tacit courses } \\
\text { Organizational: } \\
\text { explicit: shared if } \\
\text { required }\end{array}$ & $\begin{array}{l}\text { Academic: explicit, } \\
\text { shared if required } \\
\text { Organizational: } 0\end{array}$ \\
\hline \multicolumn{2}{|c|}{$\begin{array}{l}\text { Preferred structure } \\
\text { of } \\
\text { Knowledge sharing }\end{array}$} & $\begin{array}{l}\text { JV: Campus in China; } \\
100 \% \text { taught by UK/international } \\
\text { staff }\end{array}$ & $\begin{array}{l}\text { SB: degree course } \\
\text { entirely taught in China, } \\
\text { 50/50 delievery sharing }\end{array}$ & $\begin{array}{l}\text { DB franchise } \\
\text { Part of UK course } \\
\text { taught by local staff }\end{array}$ & $\begin{array}{l}\text { DB Validation } \\
\text { course designed and } \\
\text { taught by the local staff }\end{array}$ \\
\hline
\end{tabular}




\section{Figure 1}

Factors that influence knowledge sharing in China-UK educational alliances

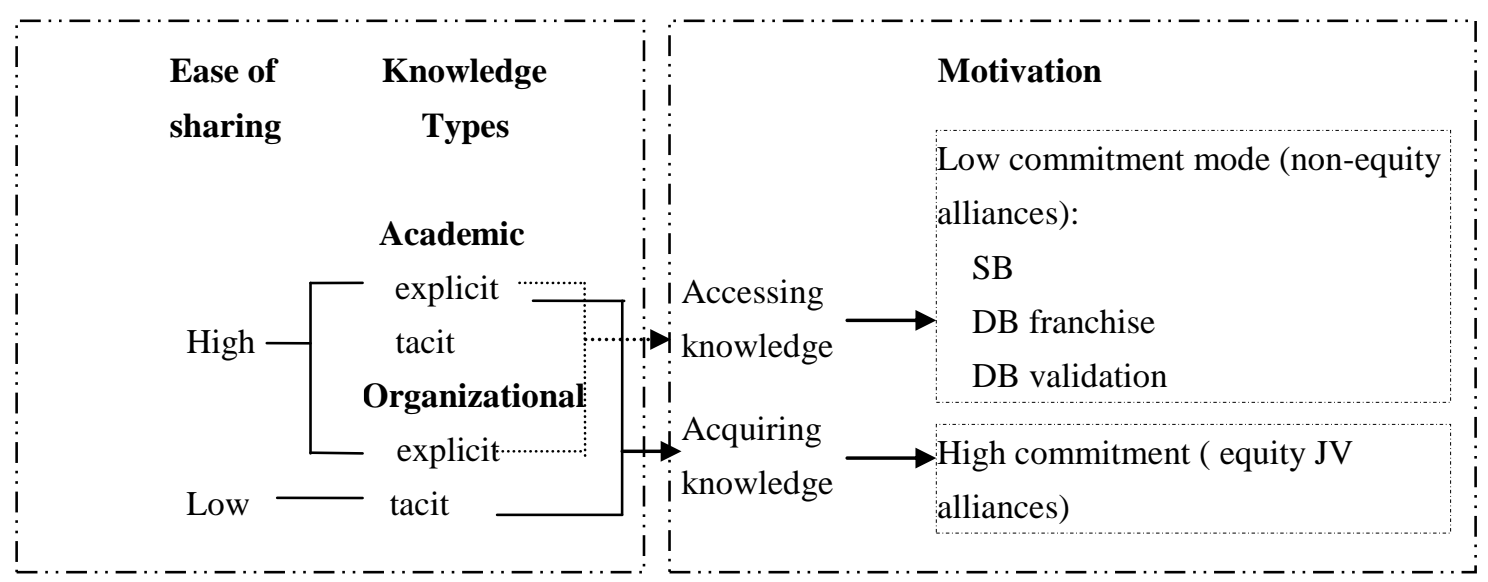

Proposition 1

Proposition 2 


\section{References:}

Ambrosini, V. \& Bowman, C. (2001). Tacit knowledge: some suggestions for operationalization, Journal of Management Studies, 38 (6), 811-829.

Anand, A. \& Singh, M.D. (2011). Understanding knowledge management: a literature review, International Journal of Engineering Science and Technology, 3(2), 926-939.

Anderson, J. (1983). The architecture of cognition. Cambridge, MA: Harvard University Press.

Argote, L. (1999). Organizational learning: creating, retaining, and transferring knowledge, Boston: Kluwer Academic.

Argote, L. \& Ingram, P. (2000). Knowledge transfer: a basis for com

Bartell, M. (2003). Internationalization of universities: a university culture-based framework. Higher Education, 45, 43-70.

Becker, R. (2010). International branch campuses: new trends and directions, International Higher Education on-line, No. 58, winter 2010. Available at: http://www.bc.edu/bc_org/avp/soe/cihe/newsletter/Number58/p3_Becke r.htm. Accessed 10 June 2010.

Beamish, P. \& Berdrow, I. (2003). Learning from IJVs: the unintended outcome. Long Range Planning, 36 (3), 285-303.

Bhagat, R.S., Harveston, P.D. \& Triandis, H.C. (2002). Cultural variations in the cross-border transfer of organizational knowledge: an integrative framework. Academy of Management Review, 27 (2), 204-221.

Bjorkman, I., Stahl, G.K. \& Vaara, E. (2007). Cultural differences and capability transfer in acquisitions: the mediating roles of capability complementarity, absorptive capacity, and social integration. Journal of International Business Studies, 38 (40), $658-672$.

Bleeke, J. \& Ernst, D. (1995). Is your strategic alliance really a sale? Harvard business review, 73 (1), 97-105.

Bontis, N. \& Crossan, M.M. (1999) Managing an organizational learning system by aligning stocks and flows of knowledge. Lancaster University Organizational Learning Conference Proceedings, 150-190.

Brouthers, K. D. \& Bamossy, G. J. (2006). Post-formation processes in Eastern and Western European joint ventures, Journal of Management Studies, 43 (2), 203-229. 
Buckley, P.J. \& Casson, M.C. (1976). The future of the multinational enterprise, London: Mcmillan.

Buckley, P.J., Glaister, K. W., Klijn, E. \& Tan, H. (2009). Knowledge accession and knowledge acquisition in strategic alliances: the impact of supplementary and complementary dimensions. British Journal of Management, 20 (4), 598-609.

Chen, C.J. (2004). The effects of knowledge attribute, alliance characteristics, and absorptive capacity on knowledge transfer performance. $R \& D$ Management, 34 (3), 311-321.

Child, J., Faulkner, D. \& Tallman, S., 2005. Cooperative Strategy: Managing Alliances, Networks, and Joint Ventures, Oxford: Oxford University Press.

Child, J. \& Rodrigues, S. (1996) 'The role of social identity in the international transfer of knowledge through joint ventures'. In S.R. Clegg and G. Palmer (Eds) The Politics of Management Knowledge, London: Sage, 46-68.

Choi, C.J. \& Lee, S.H. (1997). A knowledge-based view of cooperative interorganizational relationships, in P. Beamish and J. Killing (eds.) Cooperative strategies: European perspectives (pp. 33-58).The New Lexington Press: San Francisco.

Chou Yeh, Y.M. (2005). The implementation of knowledge management system in Taiwan's higher education. Journal of College Teaching \& Learning, 2 (9), 35-41.

Christopher, J. (2012). 'Tension between the corporate and collegial cultures of Australian public universities: The current status', Critical Perspectives on Accounting, 23(7-8), 556-571.

Coffey, A. \& Atkinson, P. (1996). Making sense of qualitative data: complementary research strategies, London: Sage.

Cohen, W.M. \& Levinthal, D.A. (1990). Absorptive capacity: a new perspective on learning and innovation. Administrative Science Quarterly, 35 (1), 128-152.

Coukos-Semmel, E. (2003). Knowledge management in research universities: the processes and strategies. The annual meeting of the American education research association, Chicago, US, 21-25 ${ }^{\text {th }}$, April 2003.

Curran, P.J. (2000). Competition in UK higher education: competitive advantage in the research assessment exercise and Porter's diamond model, Higher Education Quarterly, 54 (4), 386-410. 
Daft, R. L. (1980). The evolution of organization analysis in ASQ, 1959-1979. Administrative Science Quarterly. 25(4), 623-636.

Denman, B. (2000). Globalization and its impact on international university cooperation. Paper presented at the Organization for Economic Cooperation and Development-Program on Institutional Management in Higher Education Conference, Paris, September 2000.

Dey, I. (1993). Qualitative Data Analysis: A User Friendly Guide for Social Scientists, London: Rutledge.

Dyerson, D. \& Roper, M. (1991). When expertise becomes know-how: technology management in financial services, Business Strategy Review, 2 (2), 55-73.

Easterby-Smith, M., \& Araujo, L. J. (1999). Organizational learning: Current debates and opportunities, in M. EasterbySmith, J. Burgoyne, \& L. Araujo (Eds), Organizational learning and the learning organization (pp. 1-22). London: Sage.

Elkjaer, B. (2003). Social learning theory: Learning as participation in social process. In Easterby-Smith, M. \& Lyles, M. A. (Eds), The Blackwell handbook of organizational learning and knowledge management (pp.38-53). Malden, MA: Blackwell.

Evans, N. \& Easterby-Smith, M. (2001). 'Three types of organizational knowledge: implications for the tacit-explicit and knowledge creations debates'. In Crossan, M. and Olivera, F. (Eds), Organizational Learning and Knowledge Management. London, Ontario: The University of Western.

Fineman, S. (2003). Emotionalizing organizational learning. In M. Easterby-Smith \& M. A. Lyles (Eds), The Blackwell handbook of organizational learning and knowledge management (pp.557-574). Malden, MA: Blackwell.

Fox, S. (2000). Communities of practice, Foucault and actor-network theory. Journal of Management Studies, 37(6), 853-867.

Fralinger, B., Olson, V., Pinto-Zipp, G. \& DiCorcia, M. (2010). Organizational culture at the university level: a follow-up study using the OCAI Instrument, 2010 EABR \& ETLC Conference Proceedings, Dublin, Ireland.

Ghauri, P., Gronhaug, K. \& Kristianslund, I. (1995). Research methods in business studies-a practical guide. Cornwall, UK: Prentice Hall.

Grant, R.M. (1996). Prospering in dynamically competitive environments: organizational capability as knowledge integration. Organization Science, (7), 375-387. 
Grant, R.M. \& Baden-Fuller, C. (2004). A knowledge accessing theory of strategic alliances. Journal of Management Studies, 41(1), 61-84.

Guzman, G. \& Trivelato, L.F. (2011). Packaging and unpackaging knowledge in mass higher education - a knowledge management perspective, Higher Education, 62, 451-465.

Hansen, M. T. (2002). Knowledge networks: Explaining effective knowledge sharing in multiunit companies. Organization Science, 13(3), 232-248.

HEA (2012). Framework Guidance Note 3: What are the Dimensions? The Higher Education Academy, UK.

Hellawell, D. \& Hancock, N. (2001). A case study of the changing role of the academic middle manager in higher education: between hierarchical control and collegiality? Research Papers in Education, 16, 183-197.

Inkpen, A. C. \& Dinur, A. (1998). Knowledge management processes and international joint ventures. Organization Science, 9 (4), 454-68.

Inkpen, A.C. (2000). Learning through joint ventures: a framework of knowledge acquisition. Journal of Management Studies, 37 (7), 1019-1043.

Jankowicz, A.D. (1991). Business research projects for students. London: Chapman and Hall.

Johal, S., 2009. Strategic management,undergraduate course, lecture notes. School of Management, Royal Holloway University of London.

Johnson-Laird, P.N. (1983). Mental models. Cambridge: Cambridge University Press.

Kedia, B. L. \& Bhagat, R. S. (1988). Cultural constraints on transfer of technology across nations: Implications for research in international and comparative management. Academy of Management Review, 13(4), 559-571.

Keenoy, T. \& Reed, M. I. (2008). 'Managing modernization: introducing performance management in British universities': In Mazza, C., Quottrone, P. and Riccaboni, A. (eds) European Universities in Transition: Issues, Models and Cases, Edward Elgar, Cheltenhan, UK and Northampton, MA, USA, pp. 188-204.

Kim, L. (1998). Relative absorptive capacity and inter-organizational learning. Strategic Management Journa1, 19, 461-477. 
Kogut, B. (1988). Joint ventures: theoretical and empirical perspectives. Strategic Management Journal, 9(4), 319-332.

Kogut, B. \& Zander, U. (1993). Knowledge of the firm and the evolutionary theory of the multinational corporation. Journal of International Business Studies, 24 (4), 625-645.

Lam, A. (1997). Embedded firms, embedded knowledge: problems of collaboration and knowledge transfer in global cooperative ventures, Organization Studies, 18 (6), 973-996.

Lane, P.J. \& Lubatkin, M. (1998). Relative absorptive capacity and interorganizational learning. Strategic Management Journal, 19 (5), 461-477.

Lenard-Barton, D. (1992). Core capabilities and core rigidities: a paradox in managing new product development, Strategic Management Journal, 13, 111-126.

Li, S. (2008). Transnational education in China: thirty years, paper in Asia-Pacific Sub-regional Preparatory Conference for the 2009 World Conference on Higher Education, Facing Global and Local Challenges: the New Dynamics for Higher Education, 24-26 ${ }^{\text {th }}$ September 2008, Macao SAR, P.R. China.

Li, X., Faulkner, D. \& Yan, Y. (2011). The strategic stages of China-UK educational alliances: an empirical study, Asia Pacific Business Review, 17 (1), 7-24.

Li, X. \& Roberts, J. (2012). 'A Stages Approach to the Internationalization of Higher Education? The Entry of UK Universities into China, The Service Industries Journal, 32 (7), 1011-1038.

Lyles, M.A. \& Salk, J. E. (1996). Knowledge acquisition from foreign parents in international joint ventures: an empirical examination in the Hungarian context. Journal of International Business Studies, 27(5), 877-903.

Makino, S. \& Delios, A. (1996). Local knowledge transfer and performance implications for alliance formation in Asia. Journal of International Business Studies, 27, 905-927.

Marginson, S. (2004). 'Global public space and global marketplace: rethinking the public/private divide in higher education', keynote paper for SRHE conference, Bristol, 14-16 December 2004.

Meier, M. (2011). Knowledge management in strategic alliances: a review of empirical evidence. International Journal of Management Reviews, 13 (1), 1-23. 
Miles, M.B. \& Huberman, A.M. (1994). Qualitative data analysis: an expanded sourcebook, Thousand Oaks, CA: Sage Publications.

MoE (Ministry of Education). (2011). List of China-foreign cooperative programmes, 4 January, Ministry of Education, China.

Montazemi, A.R., Pittaway, J.J., Saremi, H.Q. \& Wei, Y. (2012). Factors of stickiness in transfer of know-how between MNC units, The Journal of Strategic Information Systems, 21 (1), 31-57.

Mowery, D.C., Oxley, J. E. \& Silverman, B. S. (1996). Strategic alliances and interfirm knowledge transfer, Strategic Management Journal, 17 (SI), 77-91.

Negandhi, A.R. (1968). Advanced management know-how in underdeveloped countries, California Management Review, 10 (3), 53-60.

Nelson, R. R.\& S.G. Winter, S. G. (1982). An Evolutionary Theory y of Economic Change, Cambridge, MA, The Belknap Press.

Newell, S., Robertson, M., Scarbrough, H. \& Swan, J. (2002). Managing Knowledge Work. Basingstoke: Palgrave.

Nielsen, B.B. (2007). Determining international strategic alliance performance: a multidimensional approach. International Business Review, 16 (3), 337-361.

Nonaka, I. (1994). A dynamic theory of organizational knowledge creation. Organization Science, 5 (1), 14-37.

Nonaka, I. \& Takeuchi, H. (1995). The knowledge-creating company: How Japanese firms create the dynamics of innovation. New York: Oxford University Press.

Norman, P.M. (2002). Protecting knowledge in strategic alliances: resource and relational characteristics. Journal of High Technology Management Research, 13 (2), 177-202.

Norman, P.M. (2004). Knowledge acquisition, knowledge loss, and satisfaction in high technology alliances. Journal of Business Research, 57 (6), 610-619.

OBHE (Observatory on Borderless Higher Education), 2009, 'International Branch Campuses: Markets and Strategies', The Observatory: London.

O’Dwyer, M. \& O'Flynn, E. (2005). MNC-SME strategic alliances- a model framing knowledge value as the primary predictor of governance modal choice. Journal of International Management, 11 (3), 397-416. 
Orlikowski, W. J. (2002). Knowing in practice: enacting a collective capability in distributed organizing. Organization Science, 13 (3), 249-273.

Pak, Y.S., Ra, W. \& Park, YR. (2009). Understanding IJV performance in a learning and conflict mediated context. International Business Review, 18 (5), 470-480.

Pan, Y. \& Tse, D.K. (2000). The hierarchical model of market entry modes. Journal of International Business Studies, 31(4), 535-554.

Park, B. I. (2011). Knowledge transfer capacity of multinational enterprises and technology acquisition in international joint ventures. International Business Review, 20 (1), 75-87.

Park, S.H. \& Russo, M.V. (1996). When competition eclipses cooperation: an event history analysis of joint venture failure. Management Science, 42 (6), 875-890.

Peters, T. \& Waterman, R. (1982). In search of excellence. New York: Harper and Row.

Polanyi, M. (1962). Tacit knowing: its bearing on some problems of philosophy. Reviews of Modern Physics, 34(4), 601-616.

Polanyi, M. (1966). The logic of tacit inference. Philosophy, 41 (1), 1-18.

Polanyi, M. (1997). 'The tacit dimension'. in L. Pruzak (Ed), Knowledge in organizations. Boston, MA: Butterworth-Heinemann, 135-146.

QAA (2006). UK Higher Education in China: An Overview of the Quality Assurance Arrangements. Mansfield, UK: The Quality Assurance Agency for Higher Education.

Rashman, L., Withers, E. \& Hartley, J. (2009). Organizational learning and knowledge in public service organizations: A systematic review of the literature. International Journal of Management Reviews, 11 (4), 463-494.

Ravetz, J.R. (1971). Scientific knowledge and its social problems. Oxford: Clarendon Press.

Roberts, J. (2000). From know-how to show-how? Questioning the role of information and communication technologies in knowledge transfer, Technology Analysis \& Strategic Management, 12 (4), 429-443.

Saffu, K. \& Mamman, A. (2000). Contradictions in international tertiary strategic alliances: the case from down under. The International Journal of Public Sector 
Management, 13(6), 508-518.

Sampson, R.C. (2004). Organizational choice in R\&D alliances: knowledge-based and transaction cost perspectives. Managerial Und Decision Economics, 25 (6-7), $421-436$.

Saunders, M., Philip, L. \& Adrian, T. (2003). Research methods for business students. Harlow: Prentice Hall.

Schein, E.H. (1984) Coming to a new awareness of organizational culture, Sloan Management Review, 25 (2), 3-16.

Schoenmakers, W. \& Duysters, G. (2006). Learning in strategic technology alliances. Technology Analysis \& Strategic Management, 18 (2), 245-264.

Shang Hai Jiaotong University (2008). Academic ranking of university-statistics by country. Centre for World-Class Universities, Shanghai Jiao Tong University. Available at:

http://www.arwu.org/rank2008/ARWU2008Statistics(EN).htm.

Accessed 19 February 2009.

Simonin, B.L. (1999). Ambiguity and the process of knowledge transfer in strategic Alliances. Strategic Management Journal, 20 (7), 595-623.

Spender, J.-C. (1996). Competitive advantage from tacit knowledge? Unpacking the concept and its strategic implications. in B. Moingeon and A. Edmondson (Eds), Organizational Learning and Competitive Advantage. London: Sage, 56-73.

Steensma, H.K.\& Lyles, M.A. (2000). Explaining IJV survival in a transitional economy through social exchange and knowledge-based perspectives. Strategic Management Journal, 21 (8), 831-851.

Strauss, A. \& Corbin, J. (1990). Basics of qualitative research: Ground theory procedures and techniques. Newbury Park, CA: Sage.

Szulanski, G. (1996), "Exploring internal stickiness: Impediments to the transfer of best practice within the firm", Strategic Management Journal, 17, 27-43.

Tallman, S. \& Shenkar, D. (1990). International cooperative venture strategies: outward investment and small firms from NICs. Management International Review 30(4), 299-315. 
Teece, D. J. (2003). 'The strategic management of technology and intellectual property' in D. Faulkner, and A. Campbell, The Oxford Handbook of Strategy. Oxford : Oxford University Press, p. 138.

Teichler, U. (2004). The changing debate on internationalization of higher education, Higher Education, 48, 5-26.

Thuc Anh, P.T., Baughn, C.C., Minh Hang, N.T. \& Neupert, K.E. (2006). Knowledge acquisition from foreign parents in international joint ventures: an empirical study in Vietnam. International Business Review, 15 (5), 463-487.

Tsang, E.W.K. (2002). Acquiring knowledge by foreign partners form international joint ventures in a transition economy: learning -by-doing and learning myopia. Strategic Management Journal, 23 (9), 835-854.

Tsoukas, H. (2003). Do we really understand tacit knowledge? In Easterby-Smith, M. \& Lyles, M. A. (Eds), The Blackwell handbook of organizational learning and knowledge management (pp.410-427). Malden, MA: Blackwell.

Tsoukas, H. \& Vladimirou, E. (2001). What is organizational knowledge, Journal of Management Studies, 38 (7), 973-993.

Weber, R.P., 1990. Basic Content Analysis, Newbury Park, CA: Sage.

Williams, G. (1992). An evaluation of new funding mechanisms in British higher education: some micro-economic and institutional management issues. Higher Education in Europe, 17, 65-85.

Winter, S. (1987). Knowledge and competence as strategic assets. In D. Teece (Ed.), The competitive challenge -strategies for industrial innovation and renewal (pp. 159-184). Cambridge, MA: Ballinger.

Yin, R.K. (2003). Case study research: design and methods, Thousand Oaks, CA: Sage Publications.

Zackariasson, P. \& Wilson, T.L., 2004. "Massively Multiplayer Online Games:

A 21st Century Service?" paper presented at the other players conference, Centre for Computer Games Research, IT University of Copenhagen, Denmark, 6-8 December 2004.

Zack, M.H. (1999). Managing codified knowledge. Sloan Management Review, 40(4), 45-58. 
Zander, U. \& Kogut, B. (1995). Knowledge and the speed of the transfer and imitation of organizational capabilities: and empirical test, Organization Science, 6(1), 76-92. 